\title{
The Effect of Health Education on The Knowledge and Adherence of Diet for Gout Arthritis Patients
}

\section{Anatun Aupia ${ }^{1}$}

1 Prodi Ilmu Keperawatan STIKes Hamzar Mamben Lombok Timur

\begin{tabular}{|c|c|}
\hline Article Info & Abstract \\
\hline $\begin{array}{l}\text { Article History: } \\
\text { Submitted: April } 7^{\text {th }}, 2021 \\
\text { Accepted: May 30 } 30^{\text {th }}, 2021 \\
\text { Published: May 31 } 1^{\text {st }}, 2021 \\
\text { Keywords: } \\
\text { Health Education; } \\
\text { Knowledge Level; Adherence } \\
\text { of Gout Diet }\end{array}$ & $\begin{array}{l}\text { Uric acid is the result of production by the body, so its quality can be normal } \\
\text { in the blood and urine. However, the rest of the protein metabolism of foods } \\
\text { containing purines also produces uric acid. One variable that impacts uric } \\
\text { acid levels is the knowledge a person has so that a better lifestyle can be } \\
\text { improved by providing health education. This res earch purpose is to } \\
\text { establish the effect of health education on knowledge and adherence to the } \\
\text { gout diet on gout arthritis patient. Pre-experimental with One group pretest- } \\
\text { posttest design has been used in this research. Forty-five respondents were } \\
\text { collected using total sampling and a questionnaire was used to measure the } \\
\text { data. The analysis data using the Wilcoxon Signed Rank Test showed that the } \\
\text { significance value (p-value) is about } 0.000<0.05 \text { which indicate that there is } \\
\text { an effect of health education on knowledge and adherence. It can be deduced } \\
\text { there is an effect of health education on knowledge and adherence to diet for } \\
\text { gout arthritis patients. }\end{array}$ \\
\hline
\end{tabular}

\section{PENDAHULUAN}

Sebagai negara berkembang, Indonesia masih memiliki tantangan diberbagai bidang, khususnya di bidang kesehatan yang memiliki signifikansi dalam kehidupan dan kesejahteraan masyarakat.

Penyakit tidak menular khususnya penyakit degeneratif menjadi salah satu masalah kesehatan yang perlu atensi yang kuat, mengingat masalah tersebut terus meningkat di Indonesia [1]. Secara patofisiologis Penyakit degeneratif menyerang sistem saraf, pembuluh darah, otot, dan tulang manusia. Asam urat atau artritis gout termasuk salah satu penyakit degeneratif yang prevalensinya paling banyak terjadi, dimana persendian yang penderita yang mengalami masalah. Athritis gout paling sering dijumpai pada lansia namun juga dapat dialami pada pralansia, mengingat trend dan gaya hidup yang terus berubah dan berkembang [2] .

Prevalensi gout berkisar 1-4\% di seluruh dunia dan kejadian gout berkisar 0,1-0,3\% (Singh and Gaffo, 2020). Di Indonesia, Prevalensi gout tertinggi berada di Aceh yaitu sebesar 13,26\% diikuti Bengkulu 12,11\%, Papua 10,43\% dan Bali 10,46\% (Riskesdas, 2018). Selain itu, data terbaru memaparkan bahwa Prevalensi penyakit asam urat di NTB (Nusa Tenggara Barat)

\footnotetext{
Corresponding author:

Anatun Aupia

ana_aupia@yahoo.co.id

Media Keperawatan Indonesia, Vol 4 No 2, May 2021

e-ISSN: 2615-1669

ISSN: 2722-2802

DOI: $10.26714 / \mathrm{mki} .4 .2 .2021 .120-126$
} 
menyentuh angka 5,30\%. Angka tersebut berada pada tingkat kedua tertinggi setelah osteoarthritis di Indonesia [3].

Penyakit Athritis gout timbul karena efek dari konsumsi zat purin yang berlebihan dalam tubuh. Purin akan dimetabolisme menjadi asam urat, jika kadar nya melebihi batas normal, maka ginjal tidak dapat mengeluarkan zat sisa yang ada sehingga terjadi penumpukan Kristal asam urat di persendian.

Konsumsi makanan yang ber-purin tinggi (bayam, kacang-kacangan, sarden, jeroan) dapat menyebabkan peningkatan kadar asam urat dan hiperuresemia.

Terapi diet asam urat adalah salah satu jalan untuk mengatasi permasalahan Kesehatan yang berhubungan dengan tingginya kadar asam urat dalam tubuh Terapi tersebut dapat dilakukan dengan berbagai cara salah satunya dengan metode dengan pendidikan kesehatan kepada penderita [2].

Pendidikan kesehatan adalah proses penyampaian informasi kepada individu, kelompok atau masyarakat yang dapat meningkatkan pengetahuan, ketrampilan dan sikap yang lebih baik untuk tercapainya kesehatan yang optimal [4].

Pemberian pendidikan kesehatan tentang asam urat kepada masyarakat diharapkan dapat meningkatkan pengetahuan sehingga terjadi perubahan yang baik dalam pencegahan, intervensi dan meminimalkan komplikasi penyakit asam urat. Melihat begitu pentingnya pendidikan kesehatan, maka petugas kesehatan yang bertugas memberikan pendidikan kesehatan harus memiliki pemahaman yang bagus dan ketrampilan yang baik dalam menyampaikan informasi kepada masyarakat sehingga tujuan dari pemberian informasi akan mengakibatkan perubahan perilaku kearah yang lebih baik yang dapat meningkatkan kesehatan [5].
Dari studi awal yang dilakukan peneliti, diketahui bahwa penderita gout tidak pernah diberikan pendidikan kesehatan sebelumnya dan 7 dari 10 penderita tidak mengetahui secara lengkap dan jelas tentang gout. Melihat berbagai fenomena yang terjadi tentang gout tersebut, maka tujuan dari penelitian ini adalah untuk melihat pengaruh dari pendidikan kesehatan terhadap pengetahuan dan kepatuhan diet penderita asam urat/gout.

\section{METODE}

Penelitian ini merupakan penelitian kuantatif eksperimen yang menggunakan metode pre-experimental design dengan rancangan one-group pretest-posttest design.

Sampel penelitian ini diambil dari populasi penderita asam urat di Kelurahan Ampenan Selatan dengan metode total sampling antara periode waktu bulan Januri hingga Februari 2020. Sebanyak 45 penderita asam urat yang telah memenuhi kriteria inklusi dan ekslusi telah berpartisipasi dalam penelitian ini, seperti penderita asam urat yang berdomisili di Kelurahan Ampenan Selatan dan bersedia menjadi responden. Penelitian ini menggunakan 1 kelompok eksperimen dan tidak ada kelompok kontrol. Eksperimen yang dilakukan adalah pemberian pendidikan kesehatan kepada responden tentang penyakit atritis gout dengan isi materi berupa definisi, tanda gejala sampai dengan penatalaksanaannya. Metode pendidikan kesehatan pada penelitian ini menggunakan metode penyampaian materi ceramah, yang dilakuan langsung peneliti dengan media slide power point. Penyampaian materi dilakukan selama 20 menit yang dilanjutkan dengan sesi diskusi dengan responden.

Tingkat pengetahuan responden diukur secara langsung sebelum dan sesudah dilakukannya eksperimen. Untuk tingkat kepatuhan responden diukur langsung 
sebelum dan 7 hari setelah intervensi pendidikan Kesehatan.

Satu set kuesioner yang diadospi dari Ulfiyah (2013) dan Purwanto (2017) digunakan untuk mengumpulkan data pre dan post intervensi pada penelitian ini. Kuesioner tersebut terdiri dari dua kuesioner meliputi kuesioner untuk mengukur tingkat pengetahuan tentang gout (20 item) dan tingkat kepatuhan diet (10 item) penderita gout. Nilai validitas dan reliabilitas kueasinoner tersebut berada kategori reliabilitas \& validitas yang tinggi (alpha cronbach's 0,898 dan CVI 0,9), artinya, kuesioner tersebut valid dan reliabel untuk digunakan:

Analisis data pada penelitian ini menggunakan analisa univariate untuk setiap variabel. Analisis bivariate dengan uji statistik Wilcoxon Signed Rank Test digunakan untuk mengetahui keterkaitan dua variable, dengan nilai signifikasi $P$ value $<0,05$.

Sebelum penelitian dilakukan, peneliti sudah mendapatkan ijin dari STIKes Hamzar dan Bappeda Propinsi Nusa Tenggara Barat. Prosedur pengambilan data kepada responden dilakukan dengan memenuhi kajian inform consent.

\section{HASIL}

Hasil penelitian ini menunjukkan bahwa dari total 45 sampel yang berpartisipasi dalam penelitian ini, mayoritas responden berjenis kelamin perempuan $(55,6 \%)$, termsuk dalam rentang usia 46-65 tahun (73,3\%), memiliki level pendidikan sekolah dasar $(33,3 \%)$ dan bekerja sebagai ibu rumah tangga $(31,1 \%)$.

Hasil penelitian menunjukkan bahwa sebanyak tingkat pengetahuan responden berada pada kategori kurang sebelum diberikan pendidikan Kesehatan $(64,4 \%)$ dan meningkat signifikan menjadi kategori baik $(66,7 \%)$ setelah diberikan pendidikan kesehatan.
Tabel 2 juga mendeskripsikan bahwa, bahwa responden berada pada tingkat tidak patuh terhadap dietnya sebelum pendidikan kesehatan (64,4\%) dan berubah menjadi patuh $(80 \%)$ setelah diberikan pendidikan kesehatan.

Selain itu, temuan lain pada penelitian ini menunjukkan bahwa pendidikan kesehatan memiliki pengaruh signifikan terhadap tingkat pengetahuan responden dan tingkat kepatuhan diet asam urat responden (pvalue $<0,05$ ).

Tabel 1

Karakteristik Responden ( $\mathrm{n}=45)$

\begin{tabular}{lcc}
\hline \multicolumn{1}{c}{ Indikator } & $\mathrm{f}$ & $\%$ \\
\hline Usia & & \\
26-45 tahun & 12 & 26,7 \\
46-65 tahun & 33 & 73,3 \\
\hline Jenis Kelamin & & \\
Laki-laki & 20 & 44,4 \\
Perempuan & 25 & 55,6 \\
\hline Pendidikan & & \\
SD & 15 & 33,3 \\
SMP & 13 & 28,9 \\
SMA & 11 & 24,4 \\
D3 & 2 & 4,4 \\
S1 & 4 & 8,9 \\
\hline Pekerjaan & & \\
IRT & 14 & 26,7 \\
Buruh & 12 & 17,8 \\
Wirausaha & 8 & 11,1 \\
Pegawai Swasta & 6 & 13,1 \\
PNS & 5 & 11,1 \\
\hline
\end{tabular}

Tabel 2.

Pengaruh pendidikan kesehatan terhadap tingkat pengetahuan sebelum dan setelah intervensi

\begin{tabular}{lccc}
\hline \multicolumn{1}{c}{ Indikator } & $\begin{array}{c}\text { Sebelum } \\
\text { perlakuan } \\
\mathrm{f}(\%)\end{array}$ & $\begin{array}{c}\text { Setelah } \\
\text { perlakuan } \\
\mathrm{f}(\%)\end{array}$ & $\mathrm{p}$ \\
\hline $\begin{array}{l}\text { Tingkat } \\
\text { Pengetahuan }\end{array}$ & & \\
$\quad$ Kurang & $29(64,4)$ & $2(4,4)$ & $0,000^{*}$ \\
Cukup & $9(20,0)$ & $13(28,9)$ & \\
$\quad$ Baik & $7(15,6)$ & $30(66,7)$ & \\
\hline Tingkat Kepatuhan & & & \\
$\quad$ Patuh & $16(35,6)$ & $36(80,0)$ & $0,000^{*}$ \\
Tidak patuh & $29(64,4)$ & $9(20,0)$ & \\
\hline
\end{tabular}

* Wilcoxon Signed Rank Test 


\section{PEMBAHASAN}

\section{Pendidikan Kesehatan Terhadap Pengetahuan Penderita Gout}

Berdasarkan hasil analisis statistik menggunakan uji Wilcoxon Signed Ranks Test dengan software SPSS versi 16 didapatkan nilai signifikansi $\rho=0,000$ dengan derajat kemaknaan $95 \%(\alpha=0,05)$. Oleh karena nilai signifikansi $\rho$ lebih kecil dari $\alpha$, maka hal ini mengindikasikasin adanya pengaruh pendidikan kesehatan terhadap pengetahuan penderita gout (asam urat) tentang diet asam urat. Hasil penelitian menunjukkan bahwa terjadinya perubahan sebelum dan sesudah diberikan pendidikan kesehatan tentang penyakit asam urat yaitu sebelum diberikan pendidikan kesehatan sebanyak 7 orang $(15,6 \%)$ memiliki tingkat pengetahuan baik dan sesudah diberikan pendidikan kesehatan meningkat menjadi 30 orang $(66,7 \%)$.

Pada dasarnya, semakin tinggi pendidikan seseorang, maka semakin mudah menangkap dan memahami informasi yang diberikan namun tidak dipungkiri juga walaupun pendidikan terakhir seseorang adalah SMA dan SMP, tingkat pemahaman akan suatu informasi juga tidaklah buruk seperti gambaran dari karakteristik responden dalam penelitian ini [6]. Meskipun pendidikan terakhir responden banyak yang tidak sampai sarjana, namun tingkat pengetahuan responden meningkat dari yang tadinya hanya $15,6 \%$ menjadi $66,7 \%$ setelah diberikan intervensi pendidikan kesehatan. Hal ini bisa sangat terjadi karena tingkat pengetahuan seseorang tidak hanya dipengaruhi oleh faktor pendidikan terakhir, akan tetapi dipengaruhi juga oleh faktor-faktor yang lain seperti faktor pengalaman, keyakinan, lingkungan dan media massa [7].

Lebih lanjut, dalam menerima pendidikan kesehatan, faktor usia juga merupakan elemen yang berpengaruh. Beberapa teori menyebutkan bahwa semakin muda usia seseorang, maka daya tangkap terhadap informasi yang disampaikan akan semakin mudah diserap dan diterima $[8,9]$. Namun, hal tersebut ber-oposisi dengan hasil penelitian ini bahwa mayoritas responden dalam kategori diatas usia 40 dan mereka dapat menerima informasi pendidikan kesehatan dengan baik. Hal tersebut didukung oleh penelitian sebelumnya bahwa, salah satu faktor yang membuat usia lanjut mudah menerima informasi dari pendidikan kesehatan adalah karena faktor motivasi [10]. Mereka akan termotivasi untuk bisa memahami bahwa informasi yang disampaikan melalui pendidikan kesehatan itu penting dan sangat dibutuhkan untuk kesehatan mereka yang lebih baik [11].

Selanjutnya, dalam membahas efektifitas intervensi, hasil penelitian ini sejalan dengan penelitian Kurniawan dan Isnaini (2012) yang menjelaskan bahwa pendidikan kesehatan tentang Gout Arthritis berpengaruh terhadap pengetahuan dan sikap pencegahan Gout Arthtritis pada lansia di posyandu dusun Kedungtangkil [12]. Dengan menggunakan 30 responden, penelitian tersebut menunjukkan hasil perubahan pengetahun dalam kategori yang sangat baik setelah diberikan pendidikan kesehatan. Dalam hasil penelitian tersebut juga menyebutkan subjek penelitiannya berada pada usia-usia yang masih mampu untuk menerima informasi sehingga terjadi perubahan pengetahuan setelah diberikan pendidikan.

Hasil yang sama juga ditunjukkan oleh penelitian sebelumnya dimana terjadi peningkatan pengetahuan sebelum dan sesudah dilakukan pendidikan kesehatan. Sebanyak 83\% subjek penelitiannya berada pada tingkat pengetahuan baik setelah diberikan pendidikan kesehatan yang tadinya $0 \%$ sebelum diberikan Pendidikan [13].

Adanya peningkatan pengetahuan dapat dipengaruhi oleh pemberian pendidikan kesehatan tentang penyakit asam urat. Hal 
ini membuktikan bahwa pendidikan kesehatan dapat diterima baik, bisa memahami serta meningkatkan pengetahuan responden dalam mengatasi penyakit asam urat [14].

Sebuah perlakuan pendidikan kesehatan akan menghasilkan sebuah perubahan jika individu, kelompok atau masyarakat juga memiliki kesadaran dalam dirinya [15], tidak hanya karena faktor pemberian materi dari seseorang ke orang lain [16]. Pengetahuan adalah segenap apa yang responden ketahui dan kemampuan mengenal serta mengingat kembali yang sudah dipelajari tentang penyakit asam urat. Adanya peningkatan pengetahuan akan menjadikan responden lebih berhatihati dalam menghadapi penyakit asam urat dan melakukan upaya-upaya yang tepat untuk mencegah terjadinya asam urat [17].

\section{Pendidikan Kesehatan Terhadap Kepatuhan Diet Asam Urat Pada Penderita Gout}

Dari hasil uji statistik Wilcoxon Signed Ranks Test, didapatkan pula nilai signifikansi $\rho=0,000$ dengan derajat kemaknaan 95\% $(\alpha=0,05)$ yang mengindikasikan adanya pengaruh pendidikan kesehatan terhadap kepatuhan diet asam urat pada penderita gout (asam urat). Penelitian ini menunjukkan sebanyak $80 \%$ responden berada pada kategori patuh dalam diet asam urat setelah diberikan pendidikan kesehatan. Dari hasil tersebut diketahui bahwa responden dengan kategori patuh mengalami peningkatan. Penelitian lain juga telah menunjukkan hasil yang serupa dimana pemberian informasi melalui pendidikan kesehatan memiliki pengaruh yang signifikan terhadap kepatuhan diet asam urat [18]. Penderita asam urat memiliki keingintahuan tentang makanan yang aman untuk dikonsumsi, makanan yang meningkatkan asam urat mereka dan prilaku apa saja yang tepat untuk dilakukan guna mengurangi sakit yang diderita [19]. Setelah mendapatkan informasi mengenai hal-hal tersebut, penderita akan memperbaiki prilaku-prilaku yang tidak tepat dengan menjalankan diet asam urat yang benar [14].

Hasil penelitian ini juga sejalan dengan penelitian Rahmi \& Anggun Hidayatur (2017)[20] yang menyatakan bahwa pendidikan kesehatan memiliki pengaruh yang positif terhadap pengetahuan dan kepatuhan diet rendah purin penderita gout arthritis. Dalam penelitian tersebut, subjek penelitian yang patuh dengan diet asam urat hanya sebesar $40,6 \%$ sebelum diberikan pendidikan kesehatan, dan berubah menjadi $100 \%$ setelah diberikan pendidikan kesehatan. Penelitian serupa menunjukkan bahwa pengetahuan memiliki hubungan yang signifikan dengan kepatuhan diet penderita asam urat [21]. Semakin rendah tingkat pengetahuan tentang asam urat, maka semakin rendah kepatuhan pasien dalam menjalankan diet asam uratnya [22].

Beberapa faktor yang mempengaruhi kepatuhan yaitu faktor predisposisi, pendukung dan pendorong dimana tingkat pengetahuan merupakan faktor yang termasuk didalamnya [23]. Perilaku yang didasari oleh pengetahuan yang baik, akan berpotensi memunculkan perilaku yang positif daripada perilaku yang tidak didasari oleh pengetahuan [24]. Oleh karena itu, tingkat pengetahuan responden yang baik membuat responden menjadi patuh terhadap diet asam urat. Berbeda dengan responden yang berpengetahuan kurang, mereka lebih berpotensi untuk tidak patuh dalam menjalankan diet asam urat [7].

Selain itu, faktor predisposisi lain yang mempengaruhi kepatuhan seseorang dalam menjaga diet asam urat sehat dan aman adalah usia [22]. Hasil penelitian ini menyebutkan, kebanyakan responden telah berusia lanjut. Berdasarkan penelitian sebelumnya, orang dengan usia lanjut yang juga memiliki masalah Kesehatan/penyakit pada dirinya, cenderung merasa takut pada kematian dan akan menjaga pola makan 
agar terhindar dari bahaya komplikasi penyakit/masalah Kesehatan yang dialaminya, korelasinya dalam penelitan ini adalah asam urat $[22,25]$.

Dengan pemberian pendidikan kesehatan yang tepat, maka terjadi peningkatan pengetahuan yang dapat membuat perubahan perilaku menjadi lebih baik dengan patuh menjalankan diet asam urat yang benar.

\section{SIMPULAN}

Berdasarkan hasil penelitian dan pembahasan diatas dapat disimpulkan bahwa pendidikan kesehatan memiliki pengaruh terhadap tingkat pengetahuan dan tingkat kepatuhan responden kearah yang lebih baik

\section{UCAPAN TERIMAKASIH}

Peneliti mengucapkan terimakasih kepada semua responden penelitian yang telah ikut berpartisipasi dalam proses penelitian san semua pihak yang telah membantu dan mendukung proses penelitian ini.

\section{REFERENSI}

[1] Bustan. Epidemiologi Penyakit Tidak Menular. Jakarta: Rineka Cipta; 2010.

[2] Damayanti D. Panduan Lengkap Mencegah dan Mengurangi Asam Urat. Yogyakarta: Araska; 2013.

[3] Dalimartha. Resep Tumbuhan Obat Untuk Asam Urat. 2008: Penebar Plus; n.d.

[4] Nasution. Pendidikan Kesehatan. Jakarta: PT. Buana Ilmu Populer; 2008.

[5] Wibayawati, Riyanto. Pendidikan Kesehatan. Jakarta: EGC; 2014.

[6] Van Der Heide I, Wang J, Droomers M, Spreeuwenberg P, Rademakers J, Uiters E. The relationship between health, education, and health literacy: Results from the dutch adult literacy and life skills survey. J Health Commun 2013;18:172-84.

https://doi.org/10.1080/10810730.2013.825 668.

[7] Notoadmodjo. Promosi Kesehatan dan Prilaku Kesehatan. Jakarta: PT. Rineka Cipta; 2012.
[8] Hou SI. Health Education: Theoretical Concepts, Effective Strategies and Core Competencies. Health Promot Pract 2014;15:619-21. https://doi.org/10.1177/1524839914538045.

[9] Cusack L, Del Mar CB, Chalmers I, Gibson E, Hoffmann TC. Educational interventions to improve people's understanding of key concepts in assessing the effects of health interventions: a systematic review. Syst Rev 2018;7. https://doi.org/10.1186/s13643-0180719-4.

[10] Bjursell C. Inclusion in education later in life: Why older adults engage in education activities. Eur J Res Educ Learn Adults 2019;10:215-30. https://doi.org/10.3384/rela.20007426.rela20192.

[11] Keçeci A, Bulduk S. Health Education for the Elderly, Geriatrics, Craig S. Atwood. IntechOpen. 1st ed., Slavka Krautzek: Intech0pen; 2012, p. 153-74. https://doi.org/10.5772/33472.

[12] Kurniawan P, Isnaeni Y. Pengaruh Pendidikan Kesehatan Arthirtis Gout Terhadap Perilaku Pencegahan Arthritis Gout Pada Lansia Posyandu Kedungtangkil Karangsari Pengasih Kulonprogo Yogyakarta. Sekolah Tinggi ilmu Kesehatan 'Aisyiyah Yogyakarta, 2011.

[13] Utomo WS. Pengaruh Pemberian Kesehatan Asam Urat Terhadap Pengetahuan dan Sikap Penderita Asam Urat di Wilayah Kerja Puskesmas Gatak Sukoharjo. Universitas Muhammadiyah Surakarta, 2015.

[14] Ramsubeik K, Ramrattan LA, Kaeley GS, Singh JA. Effectiveness of healthcare educational and behavioral interventions to improve gout outcomes: a systematic review and metaanalysis. Ther Adv Musculoskelet Dis 2018;10:235-52.

https://doi.org/10.1177/1759720X18807117.

[15] Almomani MH, Rababa M, Alzoubi F, Alnuaimi K, Alnatour A, Ali RA. Effects of a health education intervention on knowledge and attitudes towards chronic non-communicable diseases among undergraduate students in Jordan. Nurs Open 2021;8:333-42. https://doi.org/10.1002/nop2.634.

[16] Mubarok, W I, Chayatin N. Ilmu Keperawatan Komunitas Pengantar dan Teori. Jakarta: Salemba Medika; 2009.

[17] Kurniawati E, Kaawoan A, Onibala F. Pengaruh Penyuluhan Kesehatan terhadap Pengetahuan dan Sikap Klien Gout Arthritis di Puskesmas Tahuna Timur Kabupaten Sanghe. J Keperawatan 2014;2.

[18] Dai A, Mulyono S, Khasanah U. Analisis Faktor Yang Berhubungan Dengan Kepatuhan Diet Gout Arthritis Pada lansia. J Islam Nurs 2020;5. 
[19] Sheng F, Fang W, Zhang B, Sha Y, Zeng X. Adherence to gout management recommendations of Chinese patients. Med (United States) 2017;96. https://doi.org/10.1097/MD.0000000000008 532.

[20] Rahmi AH. Pengaruh Pendidikan Kesehatan Tentang Penyakit Gout Terhadap Pengetahuan dan Kepatuhan Diet Purin Penderita Gout di Puskesmas Bumiaji Kotabaru. Brawijaya, 2017.

[21] Karlin L. Pengetahuan dan Kepatuhan Diet rendah Purin Pada Penderita Gout Arthritis di Desa Buhias kecamatan Siau Timur Selatan. Universitas katolik De La Salle, 2016.

[22] Perez-Ruiz F, Desideri G. Improving adherence to gout therapy: An expert review. Ther Clin
Risk Manag $2018 ; 14: 793-802$.
https://doi.org/10.2147/TCRM.S162956.

[23] Niven. Psikologi Kesehatan: Pengantar Untuk Perawat dan Profesional. Jakarta: EGC; 2009.

[24] Glanz K, Rimer BK, Wiswanath K. Health behavior and health education: Theory, research, and practice. 4th ed. Jossey-Bass: John Wiley \& Sons; 2008.

[25] Shulten P, Thomas J, Miller M, Smith M, Ahern $M$. The role of diet in the management of gout: $A$ comparison of knowledge and attitudes to current evidence. J Hum Nutr Diet 2009;22:311. https://doi.org/10.1111/j.1365277X.2008.00928.x. 